\title{
O BEM E O MAL DA ORDEM PEDAGÓGICA OU DAS RELACT̃̃ES POSSIVEIS ENTRE 0 DISCURSO RELIGIOSO E O DISCURSO PEDAGÓGICO
}

André Picanço Favacho*

RESUMO: O presente texto apresenta o argumento - na verdade, uma aposta - de que o cristianismo produziu as primeiras práticas de ensino no Ocidente e consolidou os primeiros contornos daquilo que podemos chamar discurso pedagógico, ou seja, o discurso hoje reconhecido como aquele que permite reunir alunos em um lugar específico sob a vigilância de um mestre, regidos por um conjunto de verdades resultantes de um conflito social. Esses contornos foram possíveis a partir de quatro procedimentos historicamente produzidos: o afastamento dos aprendizes das seduções pagãs ou da vida profana; a eliminação dos prazeres que o ensino das línguas latina e grega podia favorecer; o surgimento do humanismo e do contra-humanismo pedagógico; e a transformação do demônio no duplo do aprendiz. O conjunto desses procedimentos trouxe para a modernidade um arsenal de dispositivos educacionais (ou de possibilidades) que podem, ainda hoje, se atualizar na tarefa docente e na política educacional.

Palavras-chave: Discurso Pedagógico; Discurso Religioso; Genealogia Foucaultiana.

\footnotetext{
* Doutor em Educação pela Universidade de São Paulo (USP); Professor da Faculdade de Educação (FaE) e do Programa de Pós-Graduação em Educação da Universidade Federal de Minas Gerais (UFMG). E-mail: amfavacho@hotmail.com.
} 


\section{GOOD AND EVIL IN PEDAGOGICAL ORDER OR FROM THE POSSIBLE RELATIONSHIP BETWEEN RELIGIOUS AND PEDAGOGICAL DISCOURSES}

ABSTRACT: This paper forwards the argument - actually a bet - that Christianity has given birth to the first teaching practices in the West and set up the outlines of what might be called pedagogical discourse. That is, discourse we today acknowledge as allowing students to meet at a specific place under the surveillance of a teacher, all of whom governed by a set of truths arising out of a social conflict. These outlines were made possible through four procedures: the seclusion of apprentices from pagan seductions or profane life; the relinquishment of the pleasures derived from the teaching of Latin and Greek; the upsurge of humanism and counter-humanism in teaching, and the turning of the devil into the apprentice's double. This set of procedures has brought about an array of educational tools and possibilities that even in our times can be updated into teaching practices and education policies.

Keywords: Pedagogical Discourse; Religious Discourse; Foucault's Genealogy.

\section{Situando 0 debate}

Em 2008, realizei uma pesquisa sobre a função de duas figuras, a do animal e a do demônio, que, no Ocidente, foram referências discursivas fundamentais para a construção histórica da atual noção de aluno, ou seja, daqueles que se encontram na condição de aprendiz. Em 2010, publiquei alguns dados da referida pesquisa, dando prioridade à primeira figura, a do animal. $\mathrm{Na}$ ocasião, afirmava que essa figura foi utilizada principalmente pelos mestres da Antiguidade, mas também - ainda que de forma diferente - pelos mestres dos séculos XV a XVII como referência de negação na aprendizagem dos alunos. De negação porque, não desejando ver seus alunos na condição de animais (seres inferiores), os mestres da Antiguidade os levavam a conhecer bem o fardo que um animal carrega como forma de motivá-los a amar as letras e fazer com que se afastassem do triste fim reservado àqueles seres: a morte e o sofrimento. No entanto, paradoxalmente, a referência ao animal justificava as temidas surras que os mestres se permitiam dar nos alunos utilizando instrumentos próprios para açoite de animais, como a férula e o cinto de couro, além de outros instrumentos, como a palmatória. ${ }^{1}$ Vale destacar, ainda, o uso didático que os mestres faziam dos animais quando, por exemplo, repetiam os sons que eles emitem para ensinar o bê-á-bá às crianças. ${ }^{2}$ 
Entre os séculos XV e XVII, lembrar os animais na aprendizagem dos alunos ainda era uma estratégia utilizada, mas de forma bem diferente. Erasmo de Rotterdam, Lutero e Comenius, ${ }^{3}$ por exemplo, não dispensavam a comparação entre animais e aprendizes a fim de mostrar aos pais o quanto suas práticas valorizavam mais os bichos que os próprios filhos. Nesse caso, talvez estivesse em jogo a construção de uma noção de filho - talvez a de criança - que não o reduzia a mero objeto do pai, mas fazia dele um ser importante e decisivo na formação das cidades e das nações. Do século XX em diante, resta da figura do animal apenas a lembrança que nos move secretamente quando vacilamos, ao dizer: "Esse menino é um animalzinho, um cão..." ou "Não quer a escola, vai puxar carroça!"

E a figura do demônio, quando ela aparece associada aos aprendizes? Se se considerar apenas o demônio cristão, ela começa a se esboçar com a queda do Império Romano e marcará toda a Idade Média ocidental. Embora pareça contraditório, ela fornecerá os primeiros contornos para o humanismo pedagógico, pois evita - e mesmo condena as surras dadas nos aprendizes. Mas, concomitantemente, introduz neles o medo ou a culpa; constrói um tipo de literatura (os Evangelhos) que passa a exigir, no ato do ensino, a presença de um mestre (aspecto característico do discurso pedagógico) e, por fim, elimina o prazer (sensualidades ou formas de ação indesejáveis) que possa existir no conteúdo que se lê ou ensina. Aliás, este último aspecto é, no fundo, o mais importante de todos, uma vez que é ele que materializa, no ensino, o amplo empreendimento cristão: a construção de uma ética que tem na sexualidade a sua principal visada. Pode-se dizer que o discurso pedagógico cristão traduziu para o âmbito do ensino boa parte da sua cruzada contra a sexualidade grega. Parece-me que é desse lugar - da relação entre sexualidade e ensino - que o discurso pedagógico foi primeiramente posto em operação.

Mas a qual demônio me refiro?

Corazza (2002) lembra-nos da distinção entre diabo e demônio. Para ela, diabo vem "da tradução do satanás hebraico", que significa "opositor, adversário, inimigo", enquanto o termo demônio significa "gênio, espírito, inteligência" (CORAZZA, 2002, p.17). A junção diabo/demônio "começou a ocorrer na Inquisição e fortaleceu-se com a invenção do inconsciente individual na Modernidade" (CORAZZA, 
2002, p.17), quando o demônio passa a ser, ao mesmo tempo, acusador e genial; talvez, por ser genial, acusa. A autora afirma também que, "etimologicamente, o dia-bólico separa, divide, aparta. Contrapõe-se ao sim-bólico, que sintetiza, reúne, unifica" (CORAZZA, 2002, p.17).

Vilém Flusser (2005), em seu livro A história do diabo, também apresenta uma interessante análise, na qual inverte os sete pecados capitais a favor do diabo. Além disso, concede ao diabólico uma conotação positiva, por entender que ele cria a Filosofia, a Arte e a Ciência. Inverte também a função comumente atribuída ao divino e ao diabólico, afirmando que “a 'influência divina' [é] tudo que tende para a superação do tempo [e a] 'influência diabólica' é tudo aquilo que tende para a preservação do mundo no tempo" (CORAZZA, 2002, p.23). Enquanto o divino - desejoso de transcendência - dissolve o tempo e o lança às chamas para salvá-lo, o diabólico não quer dissolvê-lo, mas protegê-lo através das descobertas. Logo, diz Flusser (2005), tomar-se-ia a ira, por exemplo, não como um sentimento que contraria um deus imaginário, mas como a luta pela liberdade ética do homem no tempo presente.

Embora seja essencial e até mesmo indispensável compreender o demônio também nessa perspectiva filosófica e demonológica, ele será tomado, neste artigo, intencionalmente, como uma noção vaga, pois, como ensina Corazza (2002a), o demônio, ou o diabo, não comporta qualquer conceito científico e ultrapassa qualquer dogma religioso, político ou cultural. Ele pertence, como diz a autora, "a toda a humanidade, tanto a crentes quanto a não crentes" (CORAZZA, 2002a, p.15). Depois, porque o demônio pedagógico pode ter muitas faces, pode estar contra ou a favor de Deus, contra ou a favor do povo, contra ou a favor dos estudantes; mas pode também ser uma abertura infinita de possibilidades ou, pelo contrário, algo desejoso de aprisionar o fora, aquilo que o discurso não tolera livre, no ócio, na devassidão, na perambulação, na anormalidade, enfim, à toa, na antirregra.

Por todas essas razões, o demônio pedagógico será aqui entendido como o espaço virtual de luta no qual, de um lado, os sacerdotes se ocupavam do ensino a fim de impedir que as práticas pagãs se propagassem, enquanto, de outro, os aprendizes, na medida do possível, introduziam essas mesmas práticas na vida escolar.

Minha aposta será, portanto, a de que, nessa luta, o cristianismo produziu as primeiras práticas de ensino no Ocidente e consolidou 
os primeiros contornos daquilo que hoje alguns chamam de discurso pedagógico, ou seja, o discurso hoje reconhecido por permitir reunir alunos em um lugar específico, sob a vigilância de um mestre, regidos por um conjunto de verdades resultantes de um conflito social. ${ }^{4}$ Esses contornos, portanto, só foram possíveis a partir de quatro procedimentos historicamente produzidos: o afastamento dos aprendizes das seduções pagãs ou da vida profana; a eliminação dos prazeres que o ensino das línguas latina e grega podia favorecer; o surgimento do humanismo e do contra-humanismo pedagógico; e a transformação do demônio no duplo do aprendiz. O conjunto desses procedimentos trouxe para a modernidade um arsenal de dispositivos educacionais (ou de possibilidades) que podem, ainda hoje, se atualizar na tarefa docente e na política educacional, estabelecendo o elo entre o que se quer da escola para a vida em sociedade e a forma de obtê-lo.

\section{As seduções pagãs (a perseguição)}

Como se sabe, o paganismo cultuado até a ascensão das religiões monoteístas - especialmente o cristianismo - não desapareceu de imediato. Segundo Aymard e Auboyer (1994), a liquidação do paganismo foi assinalada somente por volta do século $\mathrm{V}$ da nossa era, quando o poder colocou-se cada vez mais a serviço da fé. Se bem analisado, o paganismo como discurso que não preconiza a submissão a um único Deus e que é afetado pelas festas e prazeres da carne foi - e ainda é um sério problema para o cristianismo. Vale dizer que as formas da sexualidade e dos prazeres em geral são, ainda hoje, talvez, mais do que nunca, um impasse para as religiões e um desafio particular para o discurso pedagógico.

A primeira e mais importante perseguição às seduções pagãs se deu ainda na Antiguidade, contra a literatura grega, fortalecendo-se a partir das escolas cristãs surgidas no início da Idade Média, em torno do século VI, denominadas cenobiais e episcopais. ${ }^{5}$

Inicialmente, essas escolas cristãs funcionavam ora ao lado das catedrais e igrejas, ora ao lado dos mosteiros, com a finalidade de substituir gradualmente a escola clássica, na qual ainda eram ensinadas as literaturas grega e latina. Tais literaturas constituíam o principal elemen- 
to a ser substituído ou eliminado do ensino, o que se dava por meio da tradução das obras à luz da doutrina religiosa. Isso se aplicava, sobretudo, à literatura grega, uma vez que não se podia eliminar totalmente o latim por ser a língua oficial para o ensino das Sagradas Escrituras.

Para Manacorda (2002), no ato dessa tradução, os sacerdotes, além de reduzirem o ensino das línguas a uma mera adaptação doutrinária, ensinavam também a separação entre o dizer e o fazer. Para o autor, tal separação não existia na educação ofertada na Antiguidade, o que significa que as escolas cristãs passaram a ensinar para uns - os inferiores - o fazer e, para outros - os superiores - o dizer, consolidando a separação entre os que deviam pensar a política e os que deviam executar as tarefas necessárias ao Estado. Mas, além dessa interpretação, existe outra, talvez mais sutil, a ser considerada: a tarefa do demônio pedagógico era ensinar aos estudantes - pobres ou ricos - a equação que transformava homens fortes, guerreiros e desbravadores em fracos, covardes, temerosos e submissos a um Deus, a um dogma; que ensinava a todos o medo, a dizer não à guerra e aos variados cultos; que ensinava, enfim, a inércia, mas também a alavancar a tão sonhada e almejada sociedade humana.

É necessário assinalar que, mesmo antes dessas escolas cristãs, o imperativo de afastar os aprendizes das seduções pagãs ou simplesmente da literatura grega já era uma premissa romana. Legisladores, senadores e sacerdotes romanos já haviam proibido a gramática e a retórica grega em suas escolas. Como resistência à aculturação grega, os romanos impediam que seus filhos estudassem nas "escolas do ócio" (para eles, típico dos gregos atenienses), considerado incompatível com a natureza rude dos homens romanos. O senador Suetônio, por exemplo, citado por Manacorda (2002, p.82), dizia: "Fomos informados também que esses tais [professores] se dão o nome de retores latinos e que em suas escolas os jovens passam o dia inteiro em ócio". Os romanos procuravam ainda impedir que mestres da retórica latina fossem preteridos em favor de autores como Cícero e Sêneca (MANACORDA, 2002, p.82).

Mais tarde, o ensino grego foi permitido em Roma, porém como trabalho escravo para os gregos capturados em guerra. Mas surgiram outras proibições, como, por exemplo, impedir que os filhos dos romanos ganhassem dinheiro com "aquilo que era indigno ensinar, mas honroso aprender” (MANACORDA, 2002, p.83) e assegurar que o cida- 
dão romano não fizesse literatura em verso como os gregos, mas apenas em prosa. Com essas medidas, os romanos acreditavam manter a tradição de cidadãos que constroem leis firmes para a cidade, as quais, ante os acontecimentos públicos e as funções privadas, "perdoavam os vencidos e dominavam os soberbos" (MANACORDA, 2002, p.85). ${ }^{6}$

Se mesmo antes do cristianismo já era clara a ideia de que as narrativas ou literaturas produziam formas de constituição do eu e de enfretamento político, é óbvio que a classe sacerdotal cristã conhecia muito bem esse processo e sabia que a literatura grega, longe de ser romântica e ociosa, era afrodisíaca e política.

Era de se esperar, portanto, que a pedagogia cristã voltasse sua atenção para as narrativas gregas, pois elas, por meio da literatura épica, poética ou helenística, divulgavam os mitos fundadores e inculcavam valores no interior daquela cultura. Os sacerdotes sabiam que as narrativas se constituíam como um campo de luta, uma relação de força importante travada no âmbito da aprendizagem dos jovens. Se não sabiam, ao menos intuíam que havia várias formas de divulgação das narrativas. Assim, os poetas épicos passavam sua visão de mundo por meio da "ficção", os sofistas por meio da persuasão e os filósofos por meio dos diálogos. Os padres cristãos medievais (assim como os professores de hoje em relação aos métodos atuais) inferiam que essas formas de ensinar lutavam entre si pelo privilégio da verdade. Vale lembrar que essas formas de divulgação da verdade se davam concomitantemente, não estavam radicalmente separadas no tempo. Além disso, era aos vencedores dessas lutas de narrativas que "as famílias nobres [...] entregavam seus filhos para que [aprendessem a] serem líderes na cidade" (VERNANT, 2002, p.205). Portanto, a literatura grega também era o meio pelo qual os gregos educavam os filhos para manterem seu prestígio e poder. ${ }^{7}$

A partir da consolidação do cristianismo, os sacerdotes romanos, de tradição helenístico-romana, tiveram que eliminar, nos novos discípulos (os medievais) e neles mesmos, qualquer vestígio dessa tradição literária (grega, em especial). Tiveram também que lutar contra a tradição hebraico-cristã, pois judaísmo e cristianismo também tenderam a se diferenciar a partir da construção de literaturas específicas. Nos termos de Manacorda (2002, p.122), embora distintas, ambas as tradições criaram literaturas de natureza bíblico-evangélica, que mostra- 
vam aos seus fiéis, com clareza, a separação entre as suas narrativas e as narrativas gregas.

Atendo-me apenas ao cristianismo, mostrarei, a seguir, o que está na base dessa tradição bíblico-evangélica da Idade Média e como ela se tornou um limiar moral para a produção do discurso pedagógico.

\section{A tradição bíblico-evangélica}

Ao que tudo indica, a tradição bíblico-evangélica é aquela que vai interrogar tanto a gramática grega quanto a literatura latina por ainda manterem incorporadas aos seus atos, nos primeiros séculos do cristianismo, as vozes de muitos deuses e povos pagãos. Ao final das contas, como diz Rostovrzeff (1973), naquele tempo, a vitória da teologia cristã ainda não era completa, embora existissem indícios de que a Bíblia já substituía os livros existentes, as artes liberais e as diversas manifestações religiosas.

Sobre essa tradição bíblico-evangélica, encontra-se, em Foucault (1999), uma consistente análise, na qual ele mostra que, tanto no seu aspecto judaico como apostólico, a Bíblia "funcionou, na maior parte dos casos, como objeção, crítica, discurso de oposição" (FOUCAULT, 1973, p.83). Porém, para ele, essa ênfase revolucionária da Bíblia não aparece nos primórdios do cristianismo, mas na segunda metade da Idade Média, quando ela se torna uma ação política de enfrentamento. Primeiro, enfrenta a história contada pelos reis e sobre os reis antigos; depois, contrapõe-se às narrativas da Antiguidade, que criavam a memória do presente. Para o filósofo, esse acontecimento - a tradição bíblicoevangélica - pode ser visto como um discurso contra-bistórico, pois, além de romper com a forma utilizada pelos historiadores reinais, os quais, contratados pelos reis, contavam a história dos impérios, opunha-se à história romana, que retirava dos atos cotidianos dos soberanos os exemplos a serem seguidos pelo povo e punha em seu lugar os exemplos de Jesus.

Para Foucault (1999), a inauguração desse discurso contra-histórico introduz uma prática ainda hoje conhecida, a repartição binária da sociedade: 
[...] de um lado, uns, do outro, os outros, os injustos e os justos, os senhores e aqueles que lhes são submissos, os ricos e os pobres, os poderosos e aqueles que só têm braços, os invasores das terras e aqueles que tremem diante deles, os déspotas e o povo ameaçador, os homens da lei presente e aqueles da pátria futura (FOUCAULT, 1999, p.86).

Porém, não parece uma infidelidade a Foucault afirmar que esse caráter contra-histórico pode ter aparecido ainda nos primeiros séculos do cristianismo, se não como um discurso forte, ao menos como silenciosa resistência. Vê-se, por exemplo, a forma como os cristãos realizavam a educação dos novos seguidores, que eram levados a se contrapor à tradição greco-romana e, no limite, a abandoná-la para, enfim, constituir a paideia cristã.

De acordo com Cambi (1999, p.193), essa paideia tinha como princípio a "imitação de Cristo" [e não do soberano]. Afirma o autor que, "no século XV, Tomás de Kempis invocará como próprios do cristão: o 'desprezo do mundo', a humildade, a solidão e o silêncio, o amor de Deus e a consciência do pecado" (CAMBI, 1999, p.163), em contraposição à vida desregrada dos reis.

Portanto, vê-se aí que o discurso contra-histórico veiculado pela Bíblia não se fez presente apenas na mística moderna, uma vez que ele gerou, desde sua invenção, esse tipo de interioridade, que nega o mundo e o soberano. Porém, por outro lado, não se pode esquecer que, desde o início da Idade Média, na verdade, desde Constantino, o cristianismo andou lado a lado com o poder soberano. Então, que tipo de oposição o discurso bíblico realizou na primeira metade da Idade Média?

Nesse quesito, Foucault (1999) diz que o pano de fundo que acompanha todo o percurso do discurso contra-histórico, até a primeira metade da Idade Média, é a luta das raças. Mas do que se trata?

Em primeiro lugar, trata-se de não tomar a luta das raças como o discurso dos oprimidos, dos subjugados, mas sim como o discurso de oposição dos diferentes inimigos entre si. Assim, deve-se atentar para as diferentes formas de oposição aos diversos poderes, configurada, sobretudo, pelas disputas entre as mais variadas seitas. Também não se pode entender o termo raça em sentido biológico estável, o que só vai ocorrer bem mais tarde. Ademais, deve-se saber que raça não é um termo absolutamente variável, pois designa dois grupos que não têm nem a 
mesma origem, nem a mesma crença, nem a mesma língua, e que só se unem por violência. Por fim, a luta das raças não coincide, inicialmente, com a prática da soberania; nos primeiros séculos da era cristã, um não representava o outro. Quando a luta das raças começa a interferir na história contada pelo poder (interferência do cristianismo), o discurso da soberania se volta contra ele, e, finalmente, poder e cristianismo se fundem, sobretudo, quando o cristianismo foi reintroduzido na cena pública por meio do poder imperial romano.

Depois de todas as mútuas interferências, em largas linhas, o discurso contra-histórico ganha, no fim do século XVIII, o aspecto de discurso revolucionário. Para Foucault (1999, p.91), “essa ideia de revolução perpassa todo o funcionamento político e toda a história do Ocidente faz mais de dois séculos e [...] não se pode dissociá-la dessa prática contra-histórica". O filósofo ironiza, dizendo:

Não convém esquecer, afinal de contas, que Marx, no fim de sua vida, em 1882, escrevia a Engels dizendo-lhe: 'Mas, nossa luta de classes, tu sabes muito bem onde a encontramos: nós a encontramos nos historiadores franceses quando eles narravam a luta das raças"” (FOUCAULT, 1999, p.93).

Em outras palavras, o discurso contra-histórico se instaura por meio da luta das raças (múltiplas oposições), depois aparece como oposição à história contada sobre os reis (até a conversão de Constantino), chegando à noção de revolução (entre os séculos XVII e XVIII) e, por fim, nos séculos XIX e XX, é nomeado luta de classe.

Especula-se que o discurso da luta das raças, no aspecto da fusão da origem e da língua por meio da violência, ou seja, nas suas múltiplas oposições, chegou até a transição do Império Romano para a Idade Média. Produziu, portanto, por meio dos diferentes grupos étnicos ou seitas, uma oposição - ou resistência silenciosa - dos cristãos aos imperadores. Nessa época, o conflito era disperso entre as diferentes seitas, e a Igreja ainda não tinha a intenção de desqualificar os imperadores, mas sim de reeducar os pagãos.

Reeducar, nesse caso, significava consolidar entre os cristãos a ideia de Divina Providência, uma vez que se pretendia combater, segundo Aymard e Auboyer (1994), as influências do epicurismo, do estoicismo e do pitagorismo ainda presentes. Portanto, a luta das raças, em matéria de ensino, foi uma das estratégias pelas quais os cristãos passa- 
ram a evitar, em um contexto mais restrito, as seduções pagãs, legitimando formas eficazes de educação dos novos aprendizes - os pagãos. Evitar as seduções pagãs por meio das narrativas inscreve o discurso da luta das raças no interior mesmo das práticas religiosas e, ao mesmo tempo, permite criar um novíssimo discurso: o pedagógico-cristão. Tanto o discurso religioso como o pedagógico, naquele momento, nutriam-se de uma única tática: beneficiar-se da luta das raças, buscando reeducar o outro para uma nova verdade. Portanto, a luta das raças possibilitou que o discurso pedagógico cristão dominasse seus adversários, convertendo-os a uma mesma e única origem, a uma mesma e única língua e a uma mesma e única crença. Essa é a marca profunda da qual é preciso se livrar, quando possível - trazida pelo discurso pedagógico desde aquele tempo. A fim de conter ou converter o pagão, o discurso pedagógico cristão criou e silenciou o aprendiz, considerando-o demoníaco, maléfico e perigoso à sociedade. Isso pode ser confirmado, a seguir, na análise sobre as práticas educacionais do cristianismo ao longo da Idade Média.

\section{Algumas práticas educacionais do cristianismo na Idade Média}

No início da Idade Média, como já afirmado, as escolas cristãs substituíram a escola clássica e proibiram, entre outras coisas, a literatura grega, as seduções pagãs e os prazeres da carne. Tornaram-se essas as metas principais, sobretudo, do trabalho dos mestres e do ensino, cuja centralidade estava na tradução da literatura grega para o latim e no seu ensino. É também nessa época que "os membros das Igrejas passaram a reunir os alunos num mesmo ambiente, pondo fim à prática anterior dispersiva na qual os alunos se dirigiam à casa do mestre para as aulas" (VEIGA, 2007, p.19).

Nesse tempo, de fato, algo em matéria de ensino mudou radicalmente. $\mathrm{Na}$ análise que faz da tarefa pedagógica da Igreja Primitiva, Durkheim (1995) mostra que aí nasce verdadeiramente algo que até então não existia: a conversão do pagão, que se torna não só objeto da divulgação da doutrina cristã, como também objeto do discurso destinado ao ensino dos aprendizes. Na pedagogia da Igreja Primitiva, o aprendiz deixa de procurar a casa do mestre; deixa de procurar qualquer mes- 
tre; deixa de procurar vários mestres, para, enfim, se fidelizar a um único mestre, em um único local, juntamente com outros aprendizes. Dessa nova prática emergem os primeiros indícios de um exame da aprendizagem do aluno e de uma vigilância de boa parte do seu tempo sob a forma de acompanhamento do mestre.

Essa prática vai ocupar as igrejas-escolas durante toda a Idade Média. Em matéria de ensino, a Igreja, com efeito, cuidou de afastar e isolar os alunos do contato com o mundano e o profano, mas também de controlar o saber. Se, do ponto de vista da luta das raças (embate social entre grupos), a igreja apartou o aprendiz da mundanidade ou do paganismo, do ponto de vista do discurso pedagógico (guiar o outro por meio de uma verdade específica, nesse caso, a doutrina), ela colocou o aprendiz em contato com um saber que divide a realidade em duas partes: uma, considerada sagrada e legítima, e outra, profana e pecadora.

A Igreja Católica, em sua vertente pedagógica, dedicou-se, durante séculos, a esse ritual. Verger (1999) mostra que, no final da Idade Média, ela já havia não só separado os diferentes saberes, como também delimitado, de forma inquestionável, os lugares em que eles deveriam ser adquiridos. O curioso, para o autor, é que isso se dá em um momento (século XV) em que, mesmo sendo o latim valorizado, as línguas vernáculas já se desenvolviam plenamente e ocupavam um lugar de destaque, inclusive na literatura. A própria Bíblia já era traduzida para as línguas maternas (VERGER, 1999). Para ele, era exatamente por esse motivo que o latim se fortalecia, porém, agora, dentro do ensino, isto é, ele renascia "no coração das disciplinas escolares e de práticas, tanto orais como escritas, da vida política, jurídica e administrativa" (VERGER, 1999, p.32).

Pode-se dizer, com Verger (1999), que esse retorno do latim por dentro e tão somente nos espaços escolares criava para as práticas de ensino da época uma cisão profunda no saber e, por consequência, nas pessoas. De um lado, dentro dos espaços escolares, estudava-se o latim - legitimado na igreja e na escola - enquanto a totalidade da vida atuava com a língua vernácula - legitimada no campo da cultura e do povo - o que parece inaugurar a clássica separação entre o saber ensinado na escola e o ensinado na vida. Parece mesmo tratar-se da vitória cristã na separação pedagógica entre aquilo que era próprio da vida mundana e o que era específico da vida religiosa acessada pelo ensino. 
Do ponto de vista político, Verger (1999) afirma que tal separação distinguia três grupos. O primeiro, o povo, que requisitava para si aquilo que era desprezado pelos clérigos: as artes mecânicas, o lucro, a pura fantasia, o passatempo, a experimentação e as especulações. Um segundo grupo, mais específico, surgido entre o povo e formado por artesãos, engenheiros, arquitetos e cavaleiros, que desfrutavam de prestígio social, pois se acreditava que dominavam saberes dignos de serem transmitidos na relação mestre-discípulo ou patrão-empregado. Verger (1999) destaca, por exemplo, que o ofício de cavaleiro era considerado o mais importante pelo grupo de religiosos, pois os cavaleiros não eram apenas homo faber, uma vez que se dedicavam também aos exercícios físicos e militares, ao canto, à música, ao recital e, embora não dominassem muito o latim, sabiam ler e escrever. Por fim, o último grupo, formado pelos religiosos, que valorizavam o Latim, a Teologia, a Medicina e o Direito, saberes que, embora servissem para resolver as questões da vida mundana, eram considerados de inspiração divina. Esses últimos saberes eram os únicos realmente valorizados no Ocidente, ao fim da Idade Média; eles separavam e distinguiam socialmente os homens. Ou seja, quem estivesse na "escola-igreja" estava a um passo de ocupar uma posição quase divina entre os homens.

De um do ponto de vista metodológico, segundo Verger (1999), a separação entre esses saberes ocasionava, no grupo de religiosos, um interesse propriamente pedagógico por parte dos sacerdotes, qual seja, quando ensinavam Latim, Teologia, Direito ou Medicina, preservavam a forma antiga, isto é, mantinham a estrutura do texto e do pensamento conforme o modelo platônico ou o aristotélico, mas descartavam grande parte do conteúdo no momento em que o texto grego era traduzido para o latim. O conteúdo não tinha utilidade pedagógica, porém a maneira de compor o texto e de raciocinar era valorizada. Basicamente, reduziu-se a dialética e a retórica ao silogismo aristotélico, técnica demonstrativa utilizada, nesse caso, para provar a existência de Deus. Assim, preservava-se a forma em detrimento do conteúdo e aprofundava-se na moral (cristã), mas abrandava-se o pensamento (especulação). Esse mecanismo de embutir a moral no conhecimento, revelado por Verger (1999), pode ser percebido já no início da Idade Média e foi diagnosticado por Durkheim da seguinte maneira: 
Assim, o meio greco-romano no qual se fazia viver as crianças era esvaziado de tudo quanto tinha de grego e romano para tornar-se uma espécie de meio irreal, ideal, povoado, é certo, de personagens que existiram na história, mas que, apresentados assim, não tinham, por assim dizer, nada mais de histórico. Não eram mais senão figuras emblemáticas das virtudes, dos vícios, de todas as grandes paixões da humanidade. Aquiles é a coragem; Ulisses é a cautela avisada; Numa é o rei piedoso por excelência; César é o ambicioso; Augusto é o monarca poderoso e amigo das letras, etc. (DURKHEIM, 1995, p.234).

Depreende-se, portanto, que, em toda a Idade Média, em favor do estudo da Bíblia e dos saberes escolares, preservaram-se os esquemas explicativos dos filósofos gregos, enquanto se apagavam todos os vestígios do paganismo ou dos prazeres (demoníacos) provenientes do conteúdo propriamente dito.

Se o mecanismo pedagógico assim funcionava, pode-se inferir que os saberes considerados demoníacos eram todos aqueles que se contrapunham à interpretação das Sagradas Escrituras, da estrutura linguística do latim e da história contada sobre os reis. Para Verger (1999), isso era tão forte que, se alguma brecha ou saída existisse, ela estava no campo da diversão, nas leituras de romances de amor e de aventuras, destinadas, em geral, aos cavaleiros. Qualquer outro uso do latim era considerado inadmissível, afinal,

[...] a cultura erudita era, enquanto tal, coisa excessivamente séria para ser abandonada a si própria: [...] dito de outro modo, para que servem os bons conhecimentos se eles não dão margem a uma atividade concreta, útil, tanto para aquele que a produz quanto para a sociedade em que se vive? (VERGER, 1999, p.56-57).

Portanto, durante toda a Idade Média, o que se deveria oferecer nos colégios e/ou nas escolas cristãs era uma educação que levasse os mestres e os alunos a seguirem corretamente a doutrina cristã, tornando-a um saber útil aos homens, que servisse para garantir tanto o ingresso no reino dos céus quanto no circuito dos homens de poder e saber, evitando, assim, qualquer aproximação com os pagãos.

No entanto, os clérigos não imaginavam que o que eles desprezavam ou liberavam (os saberes do povo) era o próprio "demônio", e que o povo o tornaria seu "salvador", pois, na fina ironia de Flusser 
(2005), o que eram as artes mecânicas, o lucro, a pura fantasia, o passatempo, a experimentação e a especulação, senão o "demônio"?

Em resumo, vê-se nascer aí uma prática pedagógica específica: com o intuito de afastar os aprendizes das seduções pagãs, foi necessário, quando possível ou desejável, reunir e conservar os alunos em um único e mesmo lugar, acompanhando e verificando sua aprendizagem (luta das raças - embate social amplo). Além disso, o discurso pedagógico cristão cuidou de separar ou hierarquizar os diferentes saberes de acordo com a valorização social dos grupos, estabelecida pela Igreja (luta das raças); cuidou de operar cirurgicamente o saber, separando conteúdo e forma para criar outra forma e outro conteúdo (discurso pedagógico propriamente dito); enfim, cuidou de eliminar toda e qualquer dispersão que envolvia o ato de ensinar.

Enfim, ao que parece, o conjunto desses procedimentos ajudou a inventar a referência maléfica da natureza do aprendiz medieval, isto é, construiu o aluno-demônio (simulacro pedagógico da luta política). É o que será estudado a seguir.

\section{Os goliardos e outros aprendizes demoníacos}

Como é sabido, não há consenso sobre o nome goliardos: para alguns, o nome deve-se à devoção ao bispo Golias e, para outros, devese ao fato de eles comerem e beberem como Golias, inimigo da fé cristã. Apesar de serem clérigos cristãos, os goliardos eram também "estudantes vagantes, novos e diferentes herdeiros dos gyrovai [satanás] [que], condenados por São Bento, não deviam ser hóspedes agradáveis para as cidades" (MANACORDA, 2002, p.147). Entretanto, para Bartoli (1983), no fundo, um goliardo não sentia a religião como os outros religiosos: "com o cérebro no mundo antigo e na literatura pagã, com o coração que pressente o mundo moderno, que vive a volúpia, que aspira o perfume de toda beleza e quer gozá-la, o estudante vagante não tem tempo para pensar no céu" (BARTOLI, 1983, p.39). Segundo o autor, essa é a razão pela qual alguns deles dedicavam grande parte de sua vida universitária mais aos divertimentos do que aos estudos, compondo cânticos que falavam de mulheres, vinhos, caça, dinheiro e conflitos com mestres e cidadãos dos lugares por onde passavam. Aos olhos da Igreja, essa 
prática ignorava o estudo correto do latim e, por essa razão, os goliardos foram considerados pelos padres a melhor encarnação do demônio no corpo do aprendiz.

Os goliardos foram identificados pelas "vagabundagens estudantis entre as diversas universidades europeias [...] [e pelos] temas plenos de possibilidades futuras, como as ideias de moral natural e de libertinagem" (LE GOFF, 1981 apud CAMBI, 1999, p.185). Eram sedentos pelo conhecimento, fato que, aliás, deu-lhes o título de precursores do renascimento. $\mathrm{Na}$ sede pelo saber, livram-se das lições de moral e, enquanto se empenham em "percorrer cidades e o mundo [...] procuram em Paris as artes liberais, em Aureliano (Orleans) os autores, em Bolonha os códigos, em Salermo as 'pyxides', em Toledo os demônios" (BARTOLI, 1983, p.28).

Esses estudantes, ao se entregarem à desobediência, à devassidão, à luxúria, à embriaguez, à perambulação e ao ócio em detrimento dos dogmas e dos comportamentos morais, materializaram, aos olhos da Igreja, aquilo que poderia ser chamado de alunos demoníacos; no jogo discursivo sobre o aprendiz, eles receberam as marcas morais e corporais do maléfico.

Além dos goliardos, os compêndios de História da Educação fazem menção a outro grupo de estudantes maléficos, os gnósticos, citados por Mayer (1976), que foram perseguidos por serem considerados hereges, sobretudo por combaterem a Teologia do Velho Testamento nos primórdios da Era Cristã. Embora acreditassem nos mandamentos, enfatizavam ritos de iniciação secretos e mágicos, isto é, saberes que a Igreja considerava contrários a Deus.

A autonegação e o sacrifício - atividades que nem os goliardos nem os gnósticos realizavam de acordo com o previsto pela Igreja eram os principais atos que ajudavam os alunos medievais a combaterem em si as práticas consideradas diabólicas. Não obstante, surgiam outras importantes rebeliões contra a Igreja Católica, que, na tentativa de evitar rupturas no pensamento hegemônico medieval, logo diagnosticava como ações diabólicas. Todos os recursos eram utilizados para eliminar a dúvida em relação à doutrina, inclusive a proibição e a queima dos livros considerados de influência perigosa.

No meu ponto de vista, o conjunto dessas experiências consolidou, no fim da Idade Média, sobretudo entre os séculos XIV e XVI, a 
associação do aprendiz à figura do demônio, não porque o aluno seja ou fosse o demônio, mas porque a dúvida que ele poderia manifestar a respeito da doutrina o assemelhava ao demônio, isto é, ao caráter contestador. Além disso, Manacorda (2002) traz dois importantes acontecimentos históricos desse período, ambos do século XV, os quais, imagino, intensificaram essa associação. Trata-se do aparecimento das comunas e do humanismo italiano.

Criadas para atender a diferentes corporações, as comunas eram escolas que recrutavam muitos estudantes para seus ensinamentos, o que não era bem visto pela Igreja. Nessas comunas, eram formadas turmas numerosas em que eram educados não só os filhos dos comerciantes, mas, eventualmente, também outros jovens interessados e com posses. Essa situação preocupava os mais conservadores da Igreja, que, temerosos da qualidade dos mestres e do ensino, denominavam essas escolas oficinas do diabo:

[...] é necessário que os garotos sejam ensinados a ler na maneira mais honesta possível. Estando, de fato, o mundo como está, ficarão expostos a grandes perigos se os mandas aprender com religiosos e clérigos: estes são tais que 'os garotos' pouco aprenderão. Antigamente com estes cresciam os bons filhos e se formavam os homens de bem; agora tudo é terra, que produz capim para os cavalos, fogo e outras coisas. Se os mandas à 'escola comum', onde se junta uma multidão de indisciplinados, malvados, difíceis, inclinados ao mal e contrários ao bem, receio que tu percas em um ano o trabalho de sete. E se tens um 'mestre particular', há muitas dúvidas e contradições (DOMINICI apud MANACORDA, 2002, p.174).

Mediante o quadro social daquela época, pergunta-se: por que a figura do demônio aparece na escola quando ela se torna coletiva? Provavelmente, isso ocorre quando não é mais possível sustentar a educação do tipo aulas avulsas, embora se acreditasse que, enquanto coletiva ou pública, a escola propiciava o aparecimento dos alunos demoníacos, contrários ao bem. Esse contexto trazia aos pais que podiam pagar pela educação dos filhos a preocupação de que uma escola para muitos poderia transformar anjos em demônios, filhos em pecadores. Trazia também o cuidado na escolha do mestre e da instituição para os quais entregariam seus filhos. Mesmo entregando seus filhos para um religioso, com as prerrogativas doutrinárias e morais que consagravam a sua função, 
restava a dúvida de que seus filhos pudessem vir a ser endemoniados em função do contato com outros aprendizes.

Quanto ao humanismo italiano, seus representantes eram acusados de educar as crianças para o demônio e eram ostensivamente rechaçados pelos religiosos, sobretudo por recuperarem a cultura clássica e utilizarem a literatura grega em contraposição à paideia medieval. Diziam os padres: "assim crescem as crianças modernas [...] ensinandolhes todos aqueles ignominiosos males, a que levam o estudo de Ovídio Maior, das epístolas, da de arte amandi, e todos esses escritos e meretrícios" (DOMINICI apud MANACORDA, 2002, p.178). E analisa Manacorda:

É a mesma linguagem de São Bernardino de Sena, homem bonachão, ou de Gerolamo Savanarola, homem intransigente e inimigo implacável de qualquer mundanidade, portanto, os estudos clássicos e da poesia, que esbraveja contra as insídias diabólicas escondidas nos versos dos poetas pagãos, cujas histórias enganadoras sobre os deuses e os homens, falando de amores libidinosos, estultos e obscenos, 'escravizam ao demônio o homem inteiro, alma e corpo' (MANACORDA, 2002, p.178).

Elaborando um pouco mais essa ideia do humanismo italiano do século XIV, pode-se dizer que, em termos educacionais, o mais importante dessa questão não é o humanismo em si, mas o contrahumanismo que nasce a ele acoplado. Se o humanismo pedagógico do século XVI é a (re)introdução dos estudos greco-romanos no ensino e também a tentativa de eliminar, na aprendizagem, as surras e as pancadas aplicadas pelos mestres, o contra-humanismo era a censura aos textos clássicos destinados ao ensino, bem como a introdução de uma economia dos castigos que se dava via culpa e não mais por surras. Esse contra-humanismo foi o responsável por associar mais intensamente a figura do demônio ao aprendiz, exatamente por aproximá-lo do pecado.

Apesar de a figura do demônio ter acompanhado os aprendizes durante toda a Idade Média, é a partir do século XIV até próximo ao XVII que os aprendizes passam a sofrer, definitivamente, com os xingamentos que os comparam ao demônio. É também nesse conflito de humanismos que se delineia uma espécie de psicologia da aprendizagem, que se refere, sobretudo, à criança e que se assenta na ideia de que esta tem 
uma inclinação para o mal e outra para o bem e, por isso, precisa ser acompanhada mais de perto. Quer dizer, na medida em que o aprendiz não pode mais ser surrado nem ser educado individualmente (embora ainda apanhe e tenha preceptor), ele passa a ser comparado ao demônio não só por meio de xingamentos, mas também de contos que despertam nele o medo necessário para que se comporte bem e aprenda os ensinamentos dos mestres.

Ao substituir as pancadas pelas balizas demoníacas, o contrahumanismo pedagógico admitia que os estudos deveriam guiar-se mais adequadamente e, para isso, priorizar a noção cristã de criança, isto é, como idade pura e não lasciva. Nesse momento, crescem também os reclames por uma pedagogia mais serena e afetuosa. Diz Vittorino de Feltre:

[...] não [aceitar] em sua escola senão poucos alunos, e eles tinham que demonstrar inteligência e modéstia; e aqueles que não lhe resultavam adequados por inteligência e por caráter, mandava-os de volta a seus pais, exortando-os a disciplinar a vida de seus filhos de outra forma (FELTRE, [s.d.] apud MANACORDA, 2002, p.181).

Nos tempos de Cótalo, aprendiz grego, ${ }^{8}$ o aluno era considerado um animalzinho e, por isso, apanhava para se corrigir. Mas, como se tornou indigno bater nos estudantes, sobretudo nos abastados - que, no futuro próximo, poderiam ser os novos reis e rainhas e, portanto, não deveriam saber do gosto das surras e pancadas - restava aos mestres fazer com que eles compreendessem bem o lugar reservado aos alunos diabólicos e o fim que esses indignos, como eram denominados pelos padres da época medieval, teriam por se comportarem dessa forma.

No século XVI, a Contra-Reforma também atuou sobre os estudantes ditos demoníacos, apoiando-se na ideia de que a criança não se encontra em uma idade lúbrica ou sensual em si; são pecadoras por ignorância, e não por malícia. Assim, as travessuras escolares ou as indisciplinas em relação aos mestres se assemelham mais ao pecado e, portanto, trazem possibilidade de perdão.

A partir do século XVII, o cuidado com as crianças se intensifica, o que resulta na reorganização das escolas e na criação dos seminários, pois, afinal de contas, "a idade juvenil, se não for bem orientada, é levada a seguir os prazeres do mundo", afirma o Decretum de reformatione 


\section{(MANACORDA, 2002, p.202). Nesse mesmo sentido, adverte Tommaso Garzoni:}

Não existe coisa mais prejudicial ao bem dos jovens do que odiar os mestres, fugindo da escola, especialmente pelo fato de encontrá-los terríveis e severos. Deixam, portanto, os pais, escondem-se na casa de parentes, ficam brincando atrás dos muros, rondando pelas praças, escutando os saltimbancos; entram nos conventos religiosos para fazer mil matérias e, como vagabundos, não param e não têm sede permanente em nenhum lugar, fugindo da escola mais do que o demônio da Cruz, e da presença do mestre como da cara de uma serpente (GARZONI, [s.d.] apud MANACORDA, 2002, p.210).

O mesmo Tommaso Garzoni lembra que os causadores dos comportamentos inadequados das crianças e, em grande parte, a causa da perdição dos estudantes são os jogos e as brincadeiras, que deviam ser proibidos. E mais:

Sabiam as crianças que estes são seus vícios e defeitos: vozeirar nas escolas, quebrar o silêncio na ausência do mestre, dar socos a quem observa o regulamento, fazer caretas durante o coro, espiar na sala de estudo, comer castanhas às escondidas, brincar de pique-esconde, ou de primeiro e segundo com Virgílio e Cícero; brincar de trinta-e-um, fazer barquinhos de papel, caçar moscas e prendê-las em cartuchos de papel, caçar grilos para fazê-los cantar durante as aulas, trazer petecas para fazê-las voar, guardar chapinhas de chumbo na sacola para brincar, ficar pintando flores, fazendo pálios para correr, rabiscando os donatos, pintando cabeças nos guarinos, rasgando o Cato para não estudá-lo, mordendo aquele que o leva a cavalo, pedir toda hora para ir ad locum ou ad mictum 'banheiro', colar uma folha de figo na cadeira do mestre, esconder-lhe a vara magistral, recitar todos os imitadores de Ariosto no lugar das epístolas de Ovídio, sair da escola como capetinhas soltos, empurrar-se um ao outro como moleques; correr pelos muros fazendo mil loucuras, dar comida aos sapos em vez de estudar, atormentar as cobras no lugar de ler, arrancar as frutas e as flores dos outros quando se vai às indulgências, quebrar a cabeça uns dos outros por mil coisas à toa, perder tempo brincando de pinhão, de cabra-cega, de 'pandolo' ou de 'barónzola', de 'età dritta', de 'piastrele' e de outras semelhantes bobagens. Ora, são estas coisas que fazem desesperar os pais, gritar as mães, enervar os mestres; é por isso que recebem chicotadas com o chicote curtido no vinagre, varadas com a vara de espinho branco, cascudos na cabeça, bofetões na cara, pontapés no traseiro, socos na dianteira e uma 'buona mano' no dia de São Silvestre (GARZONI, [s.d.] apud MANACORDA, 2002, p.211). 
Tais comportamentos, embora já fossem há muito reprováveis, passaram, com a intensificação ou com o aparecimento cada vez mais sistematizado da escola, a ser considerados falta grave. Provavelmente, a falta de experiência dos mestres dos séculos XVI e XVII em educar grandes contingentes de alunos conduziu facilmente essas e outras travessuras às balizas demoníacas, e elas passaram a ser consideradas diabruras.

Diante dessa possível natureza maligna e demoníaca do aluno, é óbvio que a correção se daria por meio de uma linguagem educacional orientada pela religião, pela seleção rigorosa de saberes válidos e de saberes parcialmente admitidos, de forma a evitar a intromissão do mal na personalidade do aprendiz. ${ }^{9}$ Assim, as ações destinadas aos aprendizes foram muitas e cada vez mais significativas: perseguições aos pagãos, construção/tradução de uma literatura específica, vigilância do estudo, entre outras. É dessa experiência cristã de ensino que foram herdadas duas coisas em especial: a ideia de que a criança é um problema, um mal, e o sentimento de que ela ainda não é, mas será - assunto que será explorado mais adiante.

\section{De demônio a monstro}

Em tempos mais recentes, pode-se perceber que, desde Comenius, a comparação entre aprendizes e demônio já era interrogada. Talvez por sua forte inclinação em aceitar a natureza divina das coisas, Comenius (2006) os comparava mais a animais de natureza dócil do que ao demônio (natureza perversa). Rousseau (2004) também não fazia esse tipo de comparação, porém falava de outra espécie: o monstro. Previa que a sociedade transformaria o aluno em uma espécie de monstro social. Para ele, a sociedade estava demasiado corrupta para produzir alguém moralmente fortalecido. Rousseau, em seu tratado sobre educação - Emílio ou da educação - nada explicitou na direção aqui apontada (o aluno-demônio), embora tenha deixado esta pista: o aluno-monstro como resultado do tipo de sociedade em que vivia.

Entretanto, em Os anormais (2001), de Foucault, vê-se uma possibilidade de se tratar desse assunto. Diz o filósofo que o século XVIII foi marcado pela figura do monstro humano, uma espécie de exceção 
que aparece na sociedade e que faz lembrar antigas formas mitológicas, como o minotauro, composto de uma metade humana e outra animal ou com duas cabeças. Porém, o monstro privilegiado entre os séculos XVII e XVIII foi o hermafrodita, indivíduo que possui dois sexos. No Renascimento, foram os irmãos siameses e, na Idade Média, o homem bestial, cuja formação humana não havia sido concluída por Deus. Aliás, era isso que os jesuítas pensavam sobre os índios brasileiros, considerando-os metade homem e metade demônio.

Entretanto, segundo Foucault (2001), diferentemente dos outros monstros, o hermafrodita não foi poupado e não demorou muito para que atingisse um estatuto criminal; afinal, o pensamento corrente da época admitia que todo monstro provavelmente fosse um criminoso.

Contudo, em meados do século XVIII e início do século XIX, essa situação rapidamente se inverte ou reverte quando se conhece melhor a natureza do hermafrodita e se conclui que sua condição não leva à criminalidade; nesse caso, a equação muda, torna-se outra, a saber: no fundo, todo criminoso é um monstro, isto é, há algo de muito perigoso na natureza humana. Assim, não há mais um monstro biologicamente estabelecido, mas qualquer homem pode-se transformar em um terror para a sociedade.

Para Foucault (2001), o rei do final do século XVIII é o melhor exemplo de monstro social; é o próprio monstro moral, aquele que, mesmo sabendo que a punição fria e cruel cedera aos mecanismos de vigilância e controle, permanecia cometendo atrocidades. É evidente, nesse caso, a aproximação entre o rei e o criminoso ou entre o rei e qualquer um que viesse a cometer atrocidades; ambos se igualam pelo fato de cometerem infrações, ou seja, ignorarem que "o ponto supremo do seu interesse é aceitar o jogo dos interesses coletivos" (FOUCAULT, 2001, p.113). Talvez ambos - criminoso e rei - tenham, nos termos de Rousseau, rompido com o contrato social e voltado a ser "o homem da floresta", portador do "arcaísmo fundamental de antes das sociedades" (ROUSSEAU, [s.d.] apud LEIF; RUSTIN, 1968, p.74).

Se o hermafrodita deixa de ser um possível criminoso é porque todos nós nos tornamos passíveis de cometer crimes. Essa nova equação amplia os perigos, ou seja, toda e qualquer pessoa está apta a cometer crimes e, portanto, precisa ser corrigida em todos os aspectos. Em termos educacionais, as crianças precisam ser corrigidas desde cedo, 
especialmente no que diz respeito aos prazeres ou às suas atividades "sexuais", que, no século XIX, é a masturbação. Assim, a criança onanista será vigiada de perto e corrigida, uma vez que se acreditava que essa prática instigava a criança a praticar pequenas perversidades e maldades infantis.

Passa-se, então, a apostar todas as fichas na educação das crianças para que, entre outras coisas, elas não se tornassem, no futuro, indivíduos perigosos, aptos ao crime. O problema é que elas, as crianças, nessa altura, já haviam ocupado o trono de reis e rainhas, tornando-se, talvez, os novos monstros, e as escolas, uma espécie de "ovo da serpente": as crianças se tornaram o "pai do homem"."10

Todavia, na impossibilidade de todos ocuparem o trono, muitos foram considerados monstros incorrigíveis, talvez demônios; tornaram-se assassinos, lascivos, propensos ao mal e corruptores da bondosa natureza humana, nos dizeres de Rousseau.

Em termos educacionais, ficou nítida essa diferença: enquanto uns recebiam o modelo rousseauniano - carinhos e assistência familiar e política - outros eram vistos sob a ótica agostiniana como portadores de uma natureza incorrigível, maléfica e perigosa e, por isso mesmo, permanentemente vigiados. ${ }^{11}$ Para uns, boas escolas; para outros, escolas de paredes reforçadas e gradeadas; para uns, a universidade; para outros, o ensino profissionalizante, etc.

Vê-se, na verdade, que a figura do demônio ou, mais radicalmente, a figura do mal associada ao aprendiz foi um acontecimento forte e que, talvez, possa explicar a aliança entre a ordem pedagógica e a ordem religiosa ou, se quiserem, a relação entre o aprendiz e o demônio, entre a escola e a igreja, entre o professor e o padre. Pode-se dizer que, desse acontecimento, produziram-se práticas que, por mais condenáveis, ainda persistem e deixam claras suas relações com aquelas do cristianismo. Obviamente, nem todas as atuais práticas de ensino provêm das práticas cristãs de ensino ou a elas se ligam (elas também se relacionam com outras marcas), mas não custa observar os efeitos delas na atualidade. 


\section{Conclusão: 0 rasgo genealógico}

Na perspectiva de Sandra Corazza, em seu livro Para uma pedagogia do Inferno (2002), mais do que com demônio, animal ou monstro, há tempos que a prática docente teima em comparar o aluno com o mal. $\mathrm{Na}$ obra citada, Corazza realiza, com precisão, uma ousada genealogia da moral pedagógica. Afirma que o demônio moderno construído na pedagogia é o Infantil, que, por um sem número de razões, é tido como um personagem infernal que diz ao Adulto: eu sou bom, portanto você é mau (CORAZZA, 2002, p.67). Mas há também outra voz, a do Adulto, que diz ao Infantil: você é mau, portanto eu sou bom (CORAZZA, 2002, p.67). Essas vozes atestam o jogo entre o bem e o mal, constituindo o solo de um discurso pedagógico que, encurralado pelos acontecimentos descritos neste artigo, tenta substituir a primeira sentença pela segunda.

Ora, não seria nada confortável, para o professor ou para a escola, que ambos - Infantil e Adulto - fossem concebidos como maus. Mas como inverter tal sentença sem agredir física ou moralmente o Infantil, sem surrá-lo ou chamá-lo de demônio? Segundo Corazza (2002), foi necessário convocar um Deus-escravo para que o Infantil se convencesse de que estava errado. Assim, o discurso pedagógico precisou escravizar-se, enfraquecer-se, vitimar-se e adoecer frente aos alunos; enfim, precisou mortificar-se para mortificar o outro. "Ora, só pode ser um Deus-Escravo esse, que necessita das premissas da reação e da negação, do ressentimento e do niilismo passivo para obter uma conclusão que positive a si mesmo como 'bom"' (CORAZZA, 2002, p.69). E mais:

Em função de seu medo do Infantil, o Deus-Adulto da Pedagogia tem a necessidade extrema de conceber, primeiro, o Não-Eu, ou seja, o demônioInfantil como 'mau'. Então, opor-se, como Adulto, a este Não-Eu. Para, finalmente, colocar-se como 'Eu'. E, claro, encontrar o seu 'Eu-Bom'. Voltar a falar: - Você é mau; eu sou o contrário daquilo que você é; portanto, eu sou bom (CORAZZA, 2002, p.70).

Tomando o Infantil como mau, o Adulto-bom necessita se afastar de tudo aquilo que nele mesmo lembre esse Infantil, pois o bom passa a ser aquele que, nem de longe, aja como Infantil. Para evitar isso, para Corazza (2002, p.70), o adulto busca um elemento externo ou um 'terceiro adulto-divino', que pode ser "A Sociedade, A Família, A 
Revolução, A Cidadania, A Liberdade, A Democracia, O Sujeito, A Razão, O Mercado" (CORAZZA, 2002, p.70), para criar, enfim, as intenções, os objetivos e as finalidades que, amalgamadas em verdades científicas, definem todo o roteiro formativo que o Infantil deve percorrer para que sua maldade seja eliminada e, claro, para que ele entre no mundo dos bons: o mundo dos adultos.

Decorre disso que o mau do Infantil é tomado como uma força que não se separa da sua infantilidade; é força destruidora encravada na sua condição, que só a força adulta pode deter. Assim, "o infantil é mau, na medida em que não se retém, em que não acha o limite, a boa medida de sua exasperante e insuportável infantilidade" (CORAZZA, 2002, p.71).

Com efeito, a força ativa da infância, esse mau que precisa ser exorcizado, será tanto mais forte quanto mais fraco for aquele que tentar detê-la. Forte é aquele que consegue reagir a essa força e fraco é aquele que tem tudo para reagir e não o faz (contra o qual o mau do Infantil volta-se impiedosamente). Criou-se, de um lado, um discurso de adoração e exaltação aos infantis-bons (os que podem e reagem à força Infantil) e, de outro, os discursos sobre os malditos (aqueles que fracassam nessa reação), para os quais são reservados os instrumentos de punição e castigo.

O discurso pedagógico moral inicia-se, pois, na negação do outro, impingindo-lhe uma forma maléfica; transforma a força criadora e ativa em um mal, e as forças subservientes e cautelosas em um bem, de modo que “o 'bom' da ética torna-se o 'mau' da moral e o 'mau' da ética torna-se o 'bom' da moral pedagógica” (CORAZZA, 2002, p.72). Ou seja, tudo o que, do ponto de vista da ética, é desconfiança, atitude, força e ruptura passa a ser, para a moral pedagógica, motivo de preocupação. Assim, a moral pedagógica põe em movimento um conjunto de discursos morais que produzem as normas, os estatutos, os contratos, os quais, evidentemente, criam os medrosos, os apavorados, os fracos e os covardes revestidos do rótulo de bons.

Admitir esse pensamento de Corazza (2002) permite realizar vários deslocamentos no interior da moral do discurso pedagógico e vislumbrar as formas pelas quais os sujeitos podem ou não se deslocar no interior das forças ativas e reativas desse discurso.

De minha parte, o que fiz foi tentar compreender como o discurso pedagógico ocidental cristão forneceu as bases para esse discurso 
pedagógico que coloca o aluno na condição do mal. E o que descobri? Que a prática religiosa cristã de ensino, forjada na luta das raças (embates sociais), ajudou a construir a primeira figura mais próxima do professor (o padre-professor) e, ao mesmo tempo, produziu a figura do aluno demônio (mais tarde monstro), forjada na comparação com o mal. No entanto, isso só foi possível porque, na contextualização que tentei traçar, considerei que as lutas reais da Idade Média fizeram do sacerdote uma espécie de professor que, no combate aos prazeres pagãos, criava as balizas necessárias para o ensino: a eliminação da dispersão dos estudantes, o controle do conteúdo profano e o acompanhamento diuturno do trabalho dos alunos (traços do discurso pedagógico?). Por outro lado, o aprendiz só poderia se submeter a essas balizas cristãs se nele fosse introduzida a natureza maligna (comparação ao demônio) e fosse eliminada toda e qualquer forma de autonomia ou liberdade de pensamento. ${ }^{12}$

Porém, como a finalidade do discurso pedagógico cristão não era necessariamente formar o padre, o pastor ou o seminarista - a menos que o propósito fosse esse - restava ao padre-professor reeducar as paixões dos alunos como se eles tivessem de ser padres. Discursivamente, sua função era introjetar no aprendiz aquilo que é "relativamente duradouro [no religioso], o uso, o ato, o 'drama', uma certa sequência rigorosa de proceduras, por outro lado [introjetar] o que é fluido [no religioso], o fim, a expectativa que se vincula à execução das tais proceduras" (NIETZSCHE, 1983, p.309).

Assim, o discurso pedagógico cristão aplicado ao aprendiz comum servia para formar não padres com o sabor de um dia poder sêlo. O que fica de duradouro é essa sequência de hábitos, exercícios, ritos, exames, dramas que ocuparão a pessoa cada dia, cada noite, enquanto for estudante. Também fica a parte fluida, essa expectativa de ter que viver tudo isso a cada nova etapa de uma escolarização que pode durar décadas. A cada etapa, sentirá ou não o sabor do fim. Se for bem-sucedido, dirá com alegria e certo regozijo o sabor dessa travessia, mostrando o quanto foi esforçado, dedicado, o quanto abdicou dos prazeres para alcançar a meta escolar. Caso tenha aprendido a burlar as regras da escola sem ser punido, simplesmente dirá, para os mais íntimos, o quanto foi esperto nessa travessia. Mesmo se não foi bem-sucedido, aprenderá o sabor da travessia, afinal, de acordo com Nietzsche, a consciên- 
cia, para os cristãos, se impõe, sobretudo, pelo sacrifício e pela dor; é através dela que o homem aprende a responder por si. Ademais, qual dor cristã é melhor que a da falta, a da reprovação ou a de estar em dívida com o outro?

Portanto, o discurso pedagógico, apoiado na boa-fé, seja na perspectiva da infância, seja na do demônio, nasceu das entranhas do discurso religioso, restando-nos agora desentranhá-lo. Afinal de contas, um e outro não são a mesma coisa ou, como ensina Nietzsche (1983), origem e finalidade não se igualam. O castigo não é o castigar; na verdade, um representa a fraqueza do outro. Em outras palavras, castigar, por ser finalidade, já é menos poderoso do que o castigo, ou apenas alerta que há ou já houve algo mais poderoso do que o simples castigar. Nesse caso, o castigo pode ser origem e o castigar é finalidade construída no decurso das forças sociais de cada tempo. Como finalidade, o que o discurso pedagógico mais realiza é ensinar o aluno a identificar e localizar menos os conteúdos formais de uma disciplina escolar qualquer do que os objetos discursivos que estão (hoje) em jogo ou que participam dos combates sociais.

Se não se pode igualar o discurso pedagógico ao discurso religioso, ao menos é preciso admitir que a linha entre um e outro é tênue, e que se está, talvez, desde o medieval, com um pé lá outro cá, isto é, a um passo de confundir a tarefa de educar com a tarefa de doutrinar. 


\section{NOTAS}

1 Estudos mostram que só em 1989 se proibiu o uso da palmatória na Inglaterra. No Brasil, a prática de bater no aluno já era censurada desde 1970, foi transformada em crime em 1980, mas só foi definitivamente abolida em 1990, com a aprovação do Estatuto da Criança e do Adolescente.

2 Os sátiros da Contra Reforma ironizavam, dizendo que, na Antiguidade, os grunhidos dos animais ajudavam os mestres a ensinar: "de fato, o jumento quando canta repete 'a, a'; o b imitando a voz das ovelhas e dos carneiros [...] 'bé, bé'; e o 'c' imitando os porcos [...] 'ce, ce' (MANACORDA, 2002, p.206).

3 De Erasmo de Rotterdam, ver Os Meninos; de Lutero, Obras Selecionadas, v.5; de Comenius, Didática Magna.

4 De um ponto de vista morfológico, ou seja, da forma, a noção de discurso pedagógico mais aceita é aquela que modernamente associa dois discursos e os transforma para fins de transmissão, ou seja, de ensino. Esse movimento já foi analisado, sobretudo, sob o nome de transposição didática (Ives Chevallard e Michel Develay) ou recontextualização (Basil Bernstein e Mário Diaz). Contudo, não irei trabalhar com essa noção de discurso, embora reconheça o seu valor. A noção de discurso com a qual trabalho vem de Foucault, aquela que admite que as práticas, nesse caso, as práticas educativas, possuem uma história, e que é marcada por descontinuidades, mas também por exterioridades, isto é, relações estabelecidas com outras histórias. No caso desse texto, minha intenção é a de apenas mostrar que a construção do discurso pedagógico não se deu sem o opoio do discurso religioso, e que, para os tempos atuais, esse acontecimento possa se tornar, para todos nós que somos educadores, uma preocupação ética. 5 Ver Durkheim, 1995; Cambi, 1999; Manacorda, 2002. Vale destacar que, ao lado dessas escolas, surgem também as escolas palacianas ou escolas palatinas, isto é, aquelas que estão dentro do palácio do soberano, onde os clérigos estudavam gramática e retórica. As cenobiais voltavam-se para a formação do monge, lá se estudavam os elementos da liturgia; as episcopais voltavam-se para a formação do clero secular, estudavam o trívio e, sobretudo, o quadrívio, e eram localizadas ao lado das igrejas. No conjunto, essas escolas atuaram até aproximadamente o século X. A partir de então, elas se consolidaram de tal maneira a ponto de inventarem um novo modelo de escola: as universidades medievais (século XI). Muitas daquelas escolas se transformaram nas próprias universidades, enquanto se abriu espaço para outro novo tipo de escola: os colégios (século XIII). Por fim, no século XV, surgem os internatos.

6 Vale a pena conferir detalhes dessa discussão em Vernant (2002) e Vernant e Naquet (1989).

7 O que dizer das lutas ou disputas travadas, ainda hoje, em torno das narrativas pedagógicas? Arroyo (2011), em seu último livro, deixa muito claro que os sujeitos da educação entendem melhor desse fato hoje, uma vez que, no centro das políticas educacionais, não estão apenas disputas teóricas, mas também de afirmação de sujeitos, de suas memórias e narrativas postas por muito tempo no ostracismo. 
8 O Mestre, Erondas (apud MANACORDA, 2002, p.59).

9 Ver Santo Agostinho - De magistro - Coleção "Os Pensadores”, São Paulo, Abril Cultural, de 1980.

10 Segundo Sigmund Freud. Ver Oscar Cirino, em Psicanálise e psiquiatria com crianças, Belo Horizonte, Autêntica, 2001.

11 Ver Oscar Cirino, em Psicanálise e psiquiatria com crianças, Belo Horizonte, Autêntica, 2001.

12 Esse fato não é natural ou inerente ao discurso pedagógico. Pelo contrário, é historicamente construído e localizado.

\section{REFERÊNCIAS}

ARROYO. Currículo, território em disputa. Petrópolis, RJ: Vozes, 2011.

BARTOLI, A. Os precursores do Renascimento. São Paulo: Parma, 1983.

AYMARD, A.; AUBOYER, I. Roma e seu império: as civilizações da unidade romana. Rio de Janeiro: Bertrand Brasil, 1994.

BERNSTEIN, B. A estruturação do discurso pedagógico: classe, códigos e controle. Petrópolis, RJ: Vozes, 1996.

CAMBI, F. História da pedagogia. São Paulo: Editora UNESP, 1999.

CORAZZA, S. Para uma filosofia do inferno na educação. Belo Horizonte: Autêntica, 2002.

DURKHEIM, E. A evolução pedagógica. Porto Alegre: Artes Médicas, 1995.

FLUSSER, V. A história do diabo. São Paulo: Annablume, 2005.

FOUCAULT, M. Os anormais. São Paulo: Martins Fontes, 2001.

FOUCAULT, M. Em defesa da sociedade. São Paulo: Martins Fontes, 1999.

LE GOFF, J. História: novos objetos. Rio de Janeiro: F. Alves, 1974.

LE GOFF, J. Uma história do corpo na Idade Média. Rio de Janeiro: Civilização Brasileira, 2006.

LEIF, J.; RUSTIN, G. Pedagogia geral: pelo estudo das doutrinas pedagógicas. 2ed. São Paulo: Editora Nacional, 1968.

LUTERO. M. Obras selecionadas. Ética: fundamentos, oração, sexualidade, educação e economia. São Leopoldo: Sinodal, 1995. v.5.

MANACORDA, M. A. História da educação: da Antigüidade aos nossos dias. 10.ed. São Paulo: Cortez, 2002.

MAYER, F. História do pensamento educacional. Rio de Janeiro: Zahar, 1976.

NIETZSCHE, F. Obras incompletas - seleção de textos de Gérard Lebrun - Coleção os Pensadores. 3ed. São Paulo: Abril Cultural, 1983.

ROSTOVZEFF, M. História de Roma. 3ed. Rio de Janeiro: Zahar, 1973.

ROTTERDAM, E. de. De pueris (Dos meninos). A civilidade pueril. São Paulo: Escala, [s.d].

ROUSSEAU, J.-J. Emílio ou da educação. 3ed. São Paulo: Martins Fontes, 2004.

VEIGA, C. História da educação. São Paulo: Ática, 2007. 
VERGER, J. Homens e saber na Idade Média. Bauru, SP: Edusc, 1999.

VERNANT, J.-P. Entre o mito e a política. 2ed. São Paulo: Editora USP, 2002.

VEYNE, P. M. Como se escreve a História. 4ed. Brasília: Editora UNB, 1998.

Recebido: 20/08/2013

Aprovado: $18 / 06 / 2013$

Contato:

Faculdade de Educação Universidade Federal de Minas Gerais

Avenida Antônio Carlos, 6627

Pampulha

CEP 31270-901

Belo Horizonte | MG | Brasil 